\title{
Do Black Lives Matter in Japan?: Teaching Race in EFL
}

\section{Michael Ellis \\ International Christian University High School}

\section{Reference Data:}

Ellis, M. (2020). Do black lives matter in Japan?: Teaching race in EFL. In P. Clements, A. Krause, \& P. Bennett (Eds.), Teacher efficacy, learner agency. Tokyo: JALT. https://doi.org/10.37546/JALTPCP2019-02

Politically polarizing issues are generally avoided in ELT materials. However, as political divides grow wider around the world, it is the responsibility of teachers to tackle these tough topics and grow wider around the world, it is the responsibility of teachers to tackle these tough topics and
inform their students about them. In this study, I conducted a 2-month unit on American slavery for Japanese high school EFL learners $(N=31)$. The goal was to impart to students the historical knowledge necessary to understand race relations in America today and then apply those lessons to their own lives. The film Twelve Years a Slave (McQueen, 2013), the accompanying graded reader (Rollason, 2014) and a teacher-made workbook were the main materials used. Each step of the unit is introduced and student learning outcomes are analyzed. Test results and response papers indicated that students were largely able to acquire the target language and understand the text but had variable success in comprehending the themes and deeper concepts of the unit. 政治的に意見の分かれる題材は、一般的に英語教授法の教材としては避けられてきた。しかし、政治的分断が世界で広が る中、教師が生徒にそれらの難しい題村を提示し、考えさせることは教師の責務であるといえる。本論では、日本人高校生の

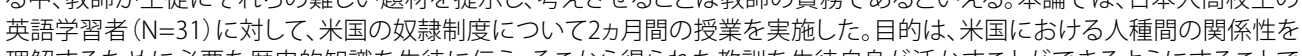
理解するために必要な歴史的知識を生徒に伝え,そこから得られた教訓を生徒自身が活かすことができるようにするてとで

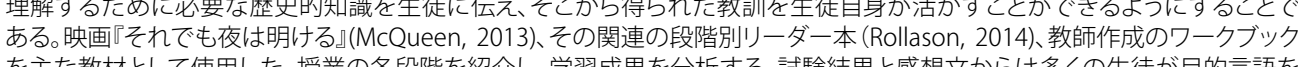
想文から多〈の生徒が目的言語を

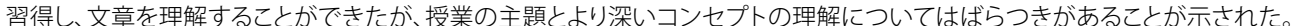

he history of American slavery and its connection with modern day race relations may seem irrelevant to the lives of Japanese EFL learners. However, given the declining Japanese population and increasing reliance on foreign residents (Coulmas,
2007), there are many lessons that Japanese people can learn from this history in order to more peacefully and productively integrate non-Japanese and multiracial Japanese citizens and residents into society today. Though $98.1 \%$ of Japanese society is still considered ethnically Japanese, the number of foreign residents is growing and is projected to continue to do so (Central Intelligence Agency, 2018). Despite this, Japan has a reputation of being unwelcoming to foreigners, even to foreign-looking Japanese people (Diene, 2006). One well-known example of this is beauty pageant contestant Ariana Miyamoto, who was born to a Japanese mother and African American father and grew up largely in Japan. As the Japanese representative at the Miss Universe pageant, she was subjected to persistent vitriol from her compatriots for not appearing sufficiently Japanese, even as a citizen with native Japanese-language proficiency (Fackler, 2015). This hostile attitude towards non-"pure" Japanese people is reflected by the government as well, which continues to give financial incentives to foreign workers of Japanese descent to leave the country (Green, 2017). For this reason, it may be more sensible to look to Japanese youth for hope. Though they are known for low voter turnouts and political apathy (Brasor, 2017), this lack of engagement may reveal an opportunity for educators to better inform their students and equip them to fight prejudice, thus supporting Japan's future socioeconomic stability.

Currently there is a lack of research on multicultural education in a Japanese EFL context, so we must turn instead to models from around the world. Au (2014) offered many principles for effective approaches, including creating classroom environments in which students can engage with social issues in ways that relate to their own lives. Bell (2010) emphasized the power of stories in education about racism and injustice to better understand and dismantle them. Adams and Bell (2016) further found that education about racism can be a productive starting point for an intersectional understanding of other forms of discrimination such as sexism, classism, and ableism, which is relevant as Japan diversifies in multiple dimensions. One model of this is the American Black Lives Matter (BLM) movement, which originally began as a response to the acquittal of 
George Zimmerman's unjust murder of a black child, Travyon Martin, in 2012, and has since grown into a network of over 40 chapters around North America with principles of fighting for restorative justice and the promotion of intersectional diversity with respect to age, gender, and sexual orientation ("Herstory," n.d.). Sawyer and Gampa (2018) studied this movement and found that the incorporation of such antiracist demonstrations in education can have positive impacts in promoting equity by reducing prejudice among individuals in both racial minorities and the racial majority. As there is no BLM chapter in Japan and political demonstrations are rare, it may be productive to use America's racist history as a backdrop to appreciate the principles of antiracist movements today. A unit based on this content may be effective in educating Japanese young people about these social issues and encouraging them to push their own country in a more culturally inclusive and diverse direction.

\section{The Study and Research Questions}

The purpose of this study is to determine whether race relations in America can be a worthwhile topic for Japanese EFL students and to provide one model for how educators might introduce it using a content and language integrated learning (CLIL) approach in a Japanese high school context (Mehisto et al., 2008). Drawing from the studies summarized above, I designed a unit around a single narrative story that I hoped would enable students to make connections from America's past to America's present and then ultimately to Japan's future. I posed two research questions:

RQ1. Can studying American race relations help Japanese EFL learners acquire English?

RQ2. Can studying American race relations help raise awareness and understanding among Japanese EFL learners about the need for racial equity?

\section{Methods}

\section{Teaching Context}

This study was conducted at a private high school in western Tokyo. The school is known for its large returnee population and reputable English program; it generally attracts students who are highly motivated to learn English. English classes at this school are divided into five levels ranging from native or near-native proficiency to EFL. The unit was delivered in the lowest level, a compulsory 11th-grade EFL course to 31 high school students in two sets of 16 and 15 . The main goal of this course was to foster students' communicative English abilities across the four skills. Classes were conducted in three 50 -minute periods a week. In total, 10 class periods were dedicated to this unit between early September and late October 2018.

\section{Materials and Procedures}

Solomon Northup's true story as a free black man kidnapped from his home in New York in 1841 and forced to work as a slave in the American south was the central topic of this unit. The main materials were the film Twelve Years a Slave (McQueen, 2013) and the accompanying graded reader (Rollason, 2014), which depict Northup's journey through his life as a slave and ultimately the reclamation of his freedom. The reader is 10,033 words long with 15,000 headwords, a standard length and complexity for intermediate high school or university Japanese learners of English. This reader and a teacher-made workbook were used to scaffold students' understanding of Northup's story and its themes.

As the first step in the unit, students were assigned summer homework at the end of the spring term in June to be completed by their first class back in September. This summer homework included a vocabulary list of 20 key words for the unit presented bilingually in English and Japanese, a reading on the history of American race relations from the slave trade through the civil rights movement, and a research task to find and summarize an article on modern day race relations in the United States. The reading was meant to contextualize Northup's story in America's history, and the research task was designed to help students understand the state of race relations in America today.

In the first class back in the fall, students took a standard vocabulary quiz that asked them to identify word-level stress, change word forms to different parts of speech, translate from Japanese to English, translate from English to Japanese, and fill in blanks by putting the target vocabulary into context. After that, students shared the article summaries that they found in small groups. Students were then given the teacher-made workbook that included a schedule to read 12 Years a Slave, divided into four subunit sections, for the rest of the unit.

Subsequent classes began with a simple comprehension quiz to confirm students' close reading of the text. These questions were straightforward with simple answers clear to those who read carefully. After checking the quizzes, class time was spent on deeper questions that encouraged inference making and elicited critical thinking. There were also extended speaking tasks such as roleplays and co-construction of a map tracing Northup's journey. Homework such as paragraph writing was also assigned. After 
Ellis: Do Black Lives Matter in Japan?: Teaching Race in EFL

reading the full book, students watched a short video explaining the Black Lives Matter movement and its activities and completed a jigsaw reading on four important racial issues that affect African Americans today, including systemic racism, racial profiling, police brutality, and political activism. They were asked to make connections between these topics and Northup's story, and a study guide that explained these connections in detail was provided at the end of class. A sample subunit containing this jigsaw reading is included in the appendix.

In the final three class periods before the midterm exams, students watched the film 12 Years a Slave in English with English subtitles. They were given a warning that some scenes are brutally violent and invited to step out to the bathroom or the nurse's office for as long as necessary if they ever felt uncomfortable. One student who is sensitive to blood spent all three classes in the nurse's office and took the DVD home to watch at his own pace.

The midterm exam on this unit had three main sections. The first was a reading comprehension section divided into three parts. First, students were provided events and asked to place them in order in the story. Second, they were provided quotes and asked to identify who said them to whom. Third, they were provided a map similar to the one they constructed in class and asked to name key places in the story. The second section of the test was short answers. Students were given six questions similar to the ones in their workbook and asked to choose three to respond to with detailed reasons supported by evidence from the text. The final section was paragraph writing. Students were asked to choose one of four prompts and respond in an academic paragraph. Student learning outcomes and the instruments used to assess them are described in the following section.

\section{Findings and Discussion}

Using Massler et al's (2014) framework, instruments were used to measure student learning outcomes with respect to language and content. A holistic measurement was also added to gauge students' general response to the unit. These specific instruments are listed in Table 1 below.

\section{Table 1. Instruments to Assess Student Learning Outcomes}

\begin{tabular}{lll}
\hline Language & Content & Holistic response \\
\hline - vocabulary quiz scores & - reading comprehension quiz & $\begin{array}{l}\text { end-of-year } \\
\text { class evaluation }\end{array}$ \\
- use of target vocabulary & scores & \\
$\begin{array}{l}\text { in two paragraphs } \\
\text { (analyzed for frequency, }\end{array}$ & exam reading comprehension & \\
variety, and accuracy) & scores & \\
& paragraph 1 (assigned as & \\
& homework) \\
& paragraph 2 (part of the exam) \\
\hline
\end{tabular}

Learning outcomes are described and analyzed by type in the following sections. All the students gave informed consent, and the study was approved by the school administration.

\section{Language}

The first instrument used to measure student acquisition of the target language was the vocabulary quiz students took after studying the list over summer vacation. The average score on this quiz was $85 \%$, which did not differ significantly from other vocabulary quizzes delivered throughout the year of different words from a similar frequency range presented in the same style. This result suggests that acquiring passive knowledge of these words was not too difficult for these students.

The second instrument was student use of this target vocabulary in two paragraphs, one assigned as homework and one as part of an exam. This instrument was designed to assess students' ability to actively use the target language in environments with and without time constraints. Table 2 below summarizes these results.

Table 2. Target Vocabulary Use Across the Two Paragraphs

\begin{tabular}{lccc}
\hline Measure & Average & Minimum & Maximum \\
\hline total word length & 323 & 196 & 462 \\
tokens of unique vocabulary words & 4.2 & 1 & 9 \\
total tokens of vocabulary words & 19.9 & 5 & 34 \\
\hline
\end{tabular}


Ellis: Do Black Lives Matter in Japan?: Teaching Race in EFL

The length of students' writing varied widely, but most were able to write at least 300 words total. Their use of the target vocabulary was also variable. An average student wrote roughly 20 tokens of four different words. This usage is broken down by word in Table 3 .

Table 3. Target Vocabulary Use Across the Two Paragraphs by Word

\begin{tabular}{|c|c|c|c|c|}
\hline Word & Frequency & $\begin{array}{c}\text { Number of } \\
\text { unique tokens }\end{array}$ & $\begin{array}{c}\text { Number of unique } \\
\text { students who used the }\end{array}$ & $\begin{array}{c}\text { Percent of } \\
\text { accurate tokens }\end{array}$ \\
\hline
\end{tabular}

\begin{tabular}{|c|c|c|c|c|}
\hline & & & $\operatorname{rd}(\Lambda$ & \\
\hline ache & $\mathrm{K}-3$ & 3 & 3 & 100 \\
\hline awful & $\mathrm{K}-1$ & 5 & 4 & 100 \\
\hline civil rights & $\mathrm{K}-3$ & 3 & 1 & 100 \\
\hline civil war & $\mathrm{K}-3$ & 2 & 2 & 100 \\
\hline cotton & $\mathrm{K}-2$ & 2 & 2 & 100 \\
\hline cruel & $\mathrm{K}-2$ & 15 & 12 & 87 \\
\hline dealer & $\mathrm{K}-1$ & 23 & 8 & 100 \\
\hline emancipate & $\mathrm{K}-7$ & 3 & 3 & 67 \\
\hline employ & $\mathrm{K}-1$ & 13 & 9 & 100 \\
\hline era & $\mathrm{K}-3$ & 2 & 2 & 50 \\
\hline lash & $\mathrm{K}-5$ & 7 & 4 & 71 \\
\hline lawyer & $\mathrm{K}-2$ & 5 & 4 & 100 \\
\hline master & $\mathrm{K}-1$ & 25 & 9 & 100 \\
\hline racial & $\mathrm{K}-3$ & 15 & 5 & 100 \\
\hline rebellion & $\mathrm{K}-3$ & 2 & 2 & 100 \\
\hline refuse & $\mathrm{K}-2$ & 9 & 8 & 100 \\
\hline slave & $\mathrm{K}-2$ & 481 & 31 & 98 \\
\hline timber & $\mathrm{K}-4$ & 1 & 1 & 100 \\
\hline violence & $\mathrm{K}-3$ & 4 & 2 & 100 \\
\hline \multirow[t]{2}{*}{ whip } & $\mathrm{K}-2$ & 16 & 8 & 88 \\
\hline & & total: 636 & & average: 97 \\
\hline
\end{tabular}

Note. Frequency was determined using the BNC/COCA word family lists developed by Nation (2012). K-1 refers to the first thousand most frequent word families (1-1,000); K-2 refers to the second thousand (1,001-2,000), and so on.
All the words were used at least once by the students, and most tokens were accurate with respect to spelling, grammatical form, and meaning. There was a weak positive correlation of $r=0.33$ between word frequency and number of tokens, with some exceptions for lower frequency words that were key to the text such as lash and racial. Overall, it seems that through the unit the students became able to actively and accurately use a large range of the target vocabulary.

\section{Content}

The first two instruments to assess student acquisition of the target content were their scores on reading comprehension quizzes and the reading comprehension section of the exam (see Table 4).

Table 4. Reading Comprehension Scores ( $N=31)$

\begin{tabular}{lc}
\hline Measure & Average score \\
\hline quizzes & $72 \%$ \\
exam part 1: events of the story & $93 \%$ \\
exam part 2: character quotes & $86 \%$ \\
exam part 3: places on the map & $66 \%$ \\
\hline
\end{tabular}

These scores suggest that students understood the content of the text to a high degree. From the exam results, it may be said that they understood the events of the story and characters better than the physical locations, which is logical when considering the relative relevance. Lessons from the bonds of Northup with his slave friends, for example, are more applicable to the students' lives than the knowledge of where Louisiana is on a U.S. map.

The next two content instruments are student responses to the two sets of paragraph prompts. In Table 5, the prompts of the homework paragraph are listed with the themes it was hoped would be evident in students' writing. Following the table, some student responses that illustrate common patterns are included unedited with errors. 
Ellis: Do Black Lives Matter in Japan?: Teaching Race in EFL

Table 5. Homework Paragraph Prompts and Target Themes $(N=31)$ Prompt Target themes

Number of students who chose

A) How did the slave trade role play make you feel? You can focus on one of the roles or write about all three (slave, dealer, and master).

B) If slavery were a common practice in Japan today, would you feel comfortable owning slaves?

C) Where and how does slavery still exist today? Find one example of modern slavery. Research and describe the lives of those slaves.
- connections between slavery and students' lives

- weight of slavery

- connections between slavery and students' lives

- weight of slavery

- connections between slavery and students' lives

- connections between history of slavery and its current forms people. Therefore, almost everyone who employ the slaves do not hurt slaves. We can be good partner with slaves." Another wrote, "If there were people who help me and communicate with me at home, and also there were no violence, I would want to be a good partner or friend of them." These students seem to see a benevolent slave owner as a hero and would celebrate such owners rather than dismantle systems like slavery from the ground up. This may be a natural conclusion from the story, as Northup passes through several masters who treat him with varying levels of cruelty.

Table 6. Exam Paragraph Prompts and Target Themes $(N=31)$

\begin{tabular}{|c|c|c|}
\hline Prompt & Target themes & $\begin{array}{l}\text { Number of } \\
\text { students } \\
\text { who chose }\end{array}$ \\
\hline
\end{tabular}

A) When Solomon learns that Eliza has died, he says "She was free at last." historical knowledge of U.S. 18 Is it better to live as a slave in the American South, or to die and become "free"?

B) Contrast the lives of male and female characters in the story. Was life during this time more difficult for the slave men or women? support, suggesting that the students were able to form coherent arguments on this heavy topic. There was, however, a vast range of maturity and depth in their responses. Most students seemed to appreciate that slavery is a horrifying practice that must never be repeated. One student wrote, "The way of thinking of slave dealers is quite strange. They think slaves as animals or tools, not as humans." Another wrote, "We are the same human. However, the slaves are always ordered by their owner. This is overt discrimination. I think my heart will always ache for them." Some students, unprompted by the teacher, were able to make connections between dark history in America and thei own country. One wrote, "Japanese junior high school students were told that it was evil that there is discrimination by status that is called 'Eta' or 'Hinin' during the Edo period. Slavery is to rank among people and I cannot admit it." The students who chose prompt $\mathrm{C}$ were all successful at researching and making connections with forms of modernday slavery such as sexual slavery and forced labor in places such as Pakistan and North Korea.

However, other students seemed to lack this appreciation for of the weight of slavery. One wrote, "Today's slaves are not unhappy. That is because, we know it is bad to hurt
C) Do people today have any responsibility for what happened in their country in the past? Why or why not?

D) What can we (as Japanese people or people living in Japan) learn examples to illustrate how we can apply these lessons.

These paragraphs all had clear topic sentences with relevant and logical support. $74 \%$ of them included specific references to the text as evidence in forming their from Solomon's story? Use specific
- historical knowledge of U.S. slavery

- intersectionality of discrimination and resulting suffering

- importance of learning from history

- importance of learning from history

- relevance to students' lives 
arguments. Like the homework paragraphs, these also exhibited a wide range of depth of understanding of the target themes.

Some students were able to tie discrimination of blacks in America to other forms of discrimination currently seen in Japan. One student wrote,

In the Solomon's story, Bass said 'In the sight of God, there's no difference between a white man and a black man.' It is not only for race relation but also for any public problems. There's no difference between a man who loves woman and a gay ... My friend hates people in China or Korea by relations between Japan and those country ... We must not see a person through race, country, and so on. We have to see a person is only a person, equally.

However, others failed to see the relevance of this story to life in Japan. One student wrote, "We can think about racial problem when we read this story. In Japan, there are no black people and all is same race [so it is a good opportunity for us]." One student failed to understand female slaves' extra burden in having to work while being tasked with raising children and coping with promiscuous masters. He wrote, "Facts are more important for men, but emotions are important for women. If they are bought as slaves, men can keep their hopes because of thir living. However women lose their hopes." We can see through these comments that students seemed to take vastly different lessons from the content of this unit.

\section{Holistic}

An end-of-year class evaluation was the instrument used to measure students' holistic responses to the unit. In the final class in March, students were asked to evaluate the usefulness of everything they did that school year on a 6-point scale. Their responses are summarized in Table 7.

Compared to all activities over the full school year, students on average found the movie 12 Years a Slave to be the most useful and the book to be the third most useful thing that they did in class. Despite the lack of understanding of the target themes by some students described above, this is an indication that students, if nothing else, enjoyed learning about the content.

\section{Limitations and Further Research}

The main limitation of this study is that students were not required to respond to every single paragraph prompt, providing only a limited view into their understanding of
Table 7. End-of-Year Class Evaluations

\begin{tabular}{lc}
\hline Was___ useful? & Rating* \\
\hline 12 Years a Slave (Movie) & 5.3 \\
Presentation 2: A Place & 5.2 \\
12 Years a Slave (Book) & 5.1 \\
Expository essay & 5.1 \\
Opinion essay & 5.0 \\
Presentation 1: A Person & 5.0 \\
NorthStar Unit 8 & 5.0 \\
Presentation 3: A Plan (PechaKucha) & 5.0 \\
Vocabulary lists & 4.9 \\
Endangered languages speaking test & 4.9 \\
NorthStar Unit 4 & 4.8 \\
Timed essay writing & 4.8 \\
NorthStar Unit 6 & 4.7 \\
NorthStar Unit 5 & 4.7 \\
Conversation strategies & 4.6 \\
Fat Tax speaking test & 4.6 \\
Vocabulary cards & 4.6 \\
NorthStar Unit 2 & 4.5 \\
Vocabulary tests & 4.5 \\
Error correction & 4.1 \\
XReading & 4.1 \\
Graded readers & 4.0 \\
Reading reports & 3.8 \\
\hline
\end{tabular}

* 6 -point scale $(1=$ not at all, $6=$ very much). 
the deep themes of the unit. This choice has pedagogical benefit, by allowing students to demonstrate how much they have learned in a best-case scenario, but also makes it difficult for researchers to determine exactly which themes students did and did not understand. For this reason, further studies in this field would benefit from more precise instruments to measure student understanding of the target content. For example, interviews conducted in Japanese with a sample of students before and after the unit might give a clearer view into if and how their perspectives on diversity and multiculturalism changed.

\section{Conclusions}

Regarding the first research question about American race relations' utility in teaching English, these results show that students were able to both understand and use some low frequency vocabulary words with a high level of accuracy. This suggests that this topic may be fertile content for EFL classes. The second research question regarding student acquisition of the target content is a bit trickier. Most students seemed to readily grasp that slavery is a horrible part of human history, but one that we must learn from in order to create a better future. A small minority were able to make connections between racism and other forms of discrimination, supporting Adams and Bell's (2016) finding that multicultural education can lead to broader intersectional tolerance and understanding. However, some students did not demonstrate this level of mature thinking. This result is a predictable one, as students in this program are divided into levels based on language proficiency, not academic aptitude. The critical thinkers were able to make these connections on their own and flourished in this challenging unit. Though this does not refute Sawyer and Gampa's (2018) study about the benefits of introducing social activism in class, it suggests that more content scaffolding may be necessary in foreign language classes to support weaker students' understanding of these complex issues.

To evaluate the overall success of this unit, it is necessary to clarify the role of the language teachers in relation to the target content, either as facilitators who encourage students to develop their own beliefs or mediators who feed them knowledge (Thomas, 2010). If as teachers we are passive facilitators of knowledge, perhaps it is not a problem that some students expressed problematic or undeveloped viewpoints in their writing. The unit gave the students opportunities to share their opinions using the target language, and they generally succeeded at this. In devising this unit, however, I took Mason's (2000) stance that as language teachers we are critical mediators of knowledge. I felt that part of my role was to encourage students to make the connections between American slavery and their own lives and to reflect on ways that Japan can become more culturally diverse and inclusive. It was therefore disappointing that some students missed this message. I thought that the connections would be easy to make in a school with a significant number of mixed race students, including students with African roots, but even at this school students needed more explicit instruction than I had anticipated. Particularly on politically charged topics such as this one, teachers must consciously develop their own balance between facilitation and mediation. Based on these results, in the future I plan to calibrate my own classes by reducing time dedicated to understanding the text and instead dedicating more time to the adjacent topics of modern day slavery, political activism, and explicit connections with Japan as well as to opportunities for students to unpack each other's views. In particular it may be useful to highlight Japanese demonstrations to help students better understand the nature and importance of political activism. Ultimately it is not a problem if a student disagrees with my beliefs about the importance of diversity in securing Japan's future. I just hope that, as a result of this unit, they can disagree using more sophisticated language and better informed arguments.

\section{Bio Data}

Michael Ellis is the EFL program coordinator at International Christian University High School. He is interested in teachers' reflective practice among many other topics and is currently program chair of TD SIG. <maikeru.desu@gmail.com>

\section{References}

Adams, M., \& Bell, L. A. (Eds.). (2016). Teaching for diversity and social justice. Oxford, England: Routledge.

Au, W. (2014). Rethinking multicultural education: Teaching for racial and cultural justice. Milwaukee, WI: Rethinking Schools.

Bell, L. A. (2010). Storytelling for social justice: Connecting narrative and the arts in antiracist teaching. Oxford, England: Routledge.

Brasor, P. (2017). Voter apathy can threaten democracy. The Japan Times. Retrieved from https://www.japantimes.co.jp

Central Intelligence Agency. (2018, February 1). The world factbook: Japan. Retrieved from https://wwaw.cia.gov/library/publications/the-world-factbook/geos/ja.html

Coulmas, F. (2007). Population decline and ageing in Japan-The social consequences. Oxford, England: Routledge. 
Ellis: Do Black Lives Matter in Japan?: Teaching Race in EFL

Diene, D. (2006). Report of the Special Rapporteur on contemporary forms of racism, racial discrimination, xenophobia and related intolerance. Mission to Japan. United Nations: United Nations Commission on Human Rights. Retrieved from https://documents-dds-ny.un.org/doc/ UNDOC/GEN/G06/103/96/PDF/G0610396.pdf?OpenElement

Fackler, M. (2015). Biracial beauty queen challenges Japan's self-image. New York Times. Retrieved from https://www.nytimes.com

Green, D. (2017). As its population ages, Japan quietly turns to immigration. Migration Policy Institute. Retrieved from https://www.migrationpolicy.org/

Herstory. (n.d.). Untitled. Retrieved from https://blacklivesmatter.com/herstory/

McQueen, S. (Director). (2013). 12 years a slave [Motion picture]. United States: Fox Searchlight Pictures.

Mason, M. (2000). Teachers as critical mediators of knowledge. Journal of Philosophy of Education, 34(2), 343-352. https://doi.org/10.1111/1467-9752.00177

Massler, U., Stotz, D., \& Queisser, C. (2014). Assessment instruments for primary CLIL: The conceptualisation and evaluation of test tasks. The Language Learning Journal, 42(2), 137-150. https://doi.org/10.1080/09571736.2014.891371

Mehisto, P., Marsh, D., \& Frigols, M. J. (2008). Uncovering CLIL content and language integrated learning in bilingual and multilingual education. Oxford, England: Macmillan.

Nation, P. (2012). The BNC/COCA word family. Retrieved from www.victoria.ac.nz/lals/about/staff/ paul-nation

Rollason, J. (2014). 12 years a slave. New York, NY: Scholastic.

Sawyer, J., \& Gampa, A. (2018). Implicit and explicit racial attitudes changed during Black Lives Matter. Personality and Social Psychology Bulletin, 44(7), 1039-1059. https://doi.org/10.1177/0146167218757454

Thomas, G. (2010). Facilitator, teacher, or leader? Managing conflicting roles in outdoor education. Journal of Experiential Education, 32(3), 239-254. https://doi.org/10.5193/JEE.32.3.239

\section{Appendix}

Sample Unit

\begin{tabular}{|l|}
\hline \multicolumn{1}{|c|}{ Chapters 12-Epilogue: Light in the Dark } \\
\begin{tabular}{|l|}
\hline Ch. 12: The Letter \\
$p 43-44$
\end{tabular} \\
\hline Ch. 13: The Fight \\
$p 45 \cdot 48$ \\
\hline Ch. 14: On The Run \\
$p 49-51$ \\
\hline Ch. 15: No Escape \\
$p 52-53$ \\
\hline Ch. 16: Two White Men \\
$p 54-56$ \\
\hline Epilogue \\
$p 57$ \\
\hline \\
\hline 1. Why does Solomon lie to Armsby? (p43) \\
\hline
\end{tabular}

2. Why does Epps say he is going to see William Ford? (p56)

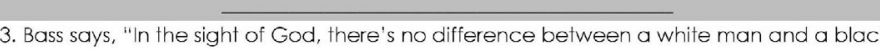

man." Is it a good idea to ignore the differences between races? (p49)

4. Solomon had three owners during his time as a slave, Ford, Tibeats and Epps. Can you 4. Solomon had three owners during his time as a slave, Ford, libeats and Epps. Can you
rank these owners from best to worst? Is it even possible to be a "good" slave owner? 
5. "Hundreds of free men and women have been sold into slavery, and at this moment are living terrible lives on plantations in Texas and Lovisiana." (p56) Solomon's story has a

(temporary) happy ending, but is saving one man from slavery truly a victory? Why (not)?

6. What happened to Solomon Northup after he disappeared?

8. Slavery is an ugly part of American history which we must learn from. Can you think of any ugly parts of Japanese history which we must also learn from?
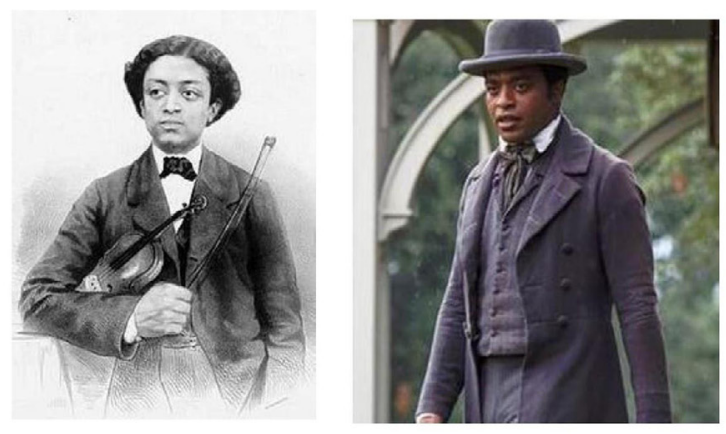

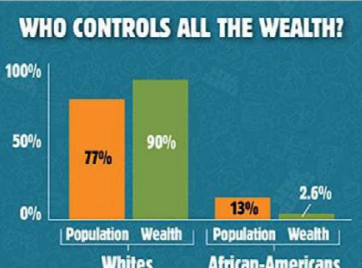

A: Systemic Racism - Some Statistic

Systemic racism is a form of racism which is expressed on a broad scale through social and political customs. It calitical power and education. Another common

example is differences in the severity of criminal justice. In the United States, blacks tend to be punished more Almost three times more blacks than whites are crimes. Whites Afitan-Ameritans arrested for dig use, even though blacks make up only ates of drug use do not differ significantly between the two populations. African Americans who have graduated college are twice as likely to be unemployed as other graduates. One study found that job applicants with white-sounding names get invited to interviews $50 \%$ mafre often than apsta cannot reason, compared to $1.8 \%$ of the rest of the population. All of these factors make it difficult for black people to advance in American society, simply because of their race.

B: Racial Profiling - Trayvon Martin Racial profiling is the act of suspecting or targeting a person based on how they lonk, rather than on their actions. Most commonly in the United States, racial proting refers to when police, without any especially African Americans, Hispanics Muslims and so on For example, police officers might be more likely to stop and search the car of a black driver than a white one. Researchers at Stanford University found that police searched $5.4 \%$ of blacks and $4.1 \%$ of Hispanics they pulled over, but only $3.1 \%$ of whites. Racial profiling is victims, and makes them feel unwelcome in their own coning for the American boy who was walke of racial profiling is Trayvon Martin, a 17 year old African neighborhood watch captain considered him a suspicious person. He followed Trayvon with his gun and shot him dead, later claiming self-defense. He had thought that Trayvon was carry

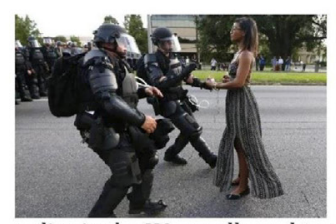

C: Police Brutality - Michael Brown

Police brutality is the use of unnecessary violence by police . It exists in many countries around the world, but in America is commonly associated with race. Police officers
tend to be crueler to people of color than to whites. $63 \%$ of people killed by police despite not holding a weapon are racial minerities, even thought these minorities make up only $23 \%$ of deadly force if they simply feel that there bray be t theat. police in the US are allowed to us dod for this excessively violent recent case of police brutality is Michael Brown Jr., an 18 year old African American man who attacked a white police officer on August 9, 2014 in Ferguson, Missouri. Brown ran away after killed him. A judge concluded the officer shot Brown in self-defense, and he was not punished. 
READING/SPEAKING TASK: Race Relations in America Today Read one of the readings on p14-15 in your numbered groups, and make sure you
understand every word. Then discuss how the content relates to Solomon's story by providing a simiar example. Return back to your normal groups and take turns explaining
puur reading. At the end of class, you should have completely filled the chart below.

: Black Lives Matter Movement - Ferguson, Missouri Baainst systemic racism BLM members organized ther hist protestin terguson, T. TI IBLACK. above.) More than five hundred members participated in
non-violent demonstrations there. They became known for
their use of social media aspecially SNS to reach large numbers of people quickly, and were recognized as one of the best organized and most visible groups in Ferguson, making them a national symbol of the movement for racial equality in America. Since then BLM has continued to grow. They hold inequality in the criminal justice system. They also rise mey providy law legal support to victims of this racial inequality. Their guiding principles include the and families, the LGBT community and members of all ages. Their ultimate goal is freedom and equality for all.
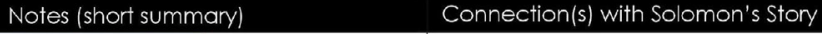

\begin{tabular}{|l|l|}
\hline \multicolumn{1}{|c|}{ A: Systemic Racism - Some Statistics } & \\
\hline B: Racial Profiling - Trayvon Martin & \\
\hline C: Police Brutality - Michael Brown & \\
& \\
\hline D: Black Lives Matter Movement - Ferguson, Missouri & \\
\hline
\end{tabular}

